\title{
POLYCULTURES OF CORIANDER, CARROT, AND ARUGULA IN STRIP-INTERCROPPING SYSTEM ${ }^{1}$
}

\author{
PAULO CÁSSIO ALVES LINHARES ${ }^{2 *}$, JAILMA SUERDA SILVA DE LIMA ${ }^{2}$, FRANCISCO BEZERRA NETO², \\ GARDÊNIA SILVANA DE OLIVEIRA RODRIGUES ${ }^{2}$, ARIDÊNIA PEIXOTO CHAVES ${ }^{2}$
}

\begin{abstract}
The objective of this research was to evaluate combinations of cultivars of coriander and arugula in two croppings with cultivars of carrot in a strip-intercropping system. The study was conducted from November 2014 to March 2015. The experimental design was a randomized complete block in a $2 \times 2 \times 2+2$ factorial scheme, with four replications. The treatments consisted of the combination of two cultivars of coriander (Verdão and Português) with two cultivars of carrot (Brasília and Esplanada) and two cultivars of arugula (Cultivada and Folha Larga) in a strip-intercropping system plus two additional treatments, where the first represents the cultivars in monocropping and the second the cultivation types (monocropping and intercropping). The characteristics evaluated in the coriander and arugula were green mass yield and shoot dry mass. The following were evaluated in carrot: shoot dry mass, dry mass of roots, total and commercial productivity, and classified productivity of roots. In the intercropping system, the agronomic indices of land equivalent ratio, productive efficiency index, and score of the canonical variable were evaluated. The economic efficiency indicators determined were gross and net income, rate of return, profit margin, monetary advantage, and modified monetary advantage. There was no significant interaction among the cultivars of coriander, carrot, and arugula for coriander and arugula green mass yields, and for total and commercial productivities of carrot roots. The best polyculture was of that involved in the cultivars "Português," "Esplanada," and "Cultivada".
\end{abstract}

Keywords: Coriandrum sativum L.. Daucus carota L.. Eruca sativa. Agronomic efficiency. Semi-arid region.

\section{POLICULTIVOS DE COENTRO, CENOURA E RÚCULA EM CONSÓRCIO EM FAIXAS}

RESUMO - O objetivo desta pesquisa foi avaliar combinações de cultivares de coentro e rúcula em bicultivo com cultivares de cenoura em sistema consorciado de faixas. O estudo foi desenvolvido de novembro de 2014 a março de 2015. O delineamento experimental utilizado foi o de blocos ao acaso, em esquema fatorial $2 \times 2 \times 2+2$, com quatro repetições. Os tratamentos consistiram da combinação de duas cultivares de coentro (Verdão e Português), com duas cultivares de cenoura (Brasília e Esplanada) e duas cultivares de rúcula (Cultivada e Folha Larga) em sistema de consórcio em faixas, mais dois tratamentos adicionais, onde o primeiro representa as cultivares em monocultivo e o segundo os tipos de cultivo (monocultivo e consórcio). As características avaliadas no coentro e na rúcula foram: rendimento de massa verde e massa seca da parte aérea. $\mathrm{Na}$ cenoura foram avaliados: massa seca da parte aérea, massa seca de raízes, produtividade total e comercial e produtividade classificada de raízes. No sistema de consórcio, foram avaliados os índices agronômicos: índice de uso eficiente de terra, índice de eficiência produtiva e pontuação da variável canônica. Os indicadores de eficiência econômica determinados foram: lucro bruto e líquido, taxa de retorno, margem de lucro, vantagem monetária e vantagem monetária corrigida. Não houve interação significativa entre as cultivares de coentro, cenoura e rúcula nos rendimentos de massa verde de coentro e de rúcula e nas produtividades total e comercial de raízes de cenoura. A melhor policultura foi a que envolveu a cultivar "Português", "Esplanada" e "Cultivada".

Palavras-chave: Coriandrum sativum L.. Daucus carota L.. Eruca sativa. Eficiência agronômica. Semiárido.

\footnotetext{
*Corresponding author

${ }^{1}$ Received for publication in $04 / 08 / 2016$; accepted in $12 / 12 / 2016$.

Paper extracted from the master thesis of the first author.

${ }^{2}$ Universidade Federal Rural do Semi-Árido, Mossoró, RN, Brazil; paulo_linhares2011@hotmail.com, jailma@ufersa.edu.br, bezerra@ufersa.edu.br, gardeniavg@yahoo.com.br, aridenia.peixoto@hotmail.com.
} 


\section{INTRODUCTION}

In the search for technological innovations for the development of cropping systems that can guarantee quality production and based on the integration and in the complexity of the biotic and abiotic factors of an agroecosystem, the intercropping system is an alternative to sustainable agriculture. This practice consists of planting two or more crops in the same area, with the aim of increasing food production per unit area, providing greater biological diversity, increasing soil protection, improving land use efficiency, and increasing utilization of resources and inputs used in crops (LIMA et al., 2013; REZENDE et al., 2005).

The success of intercropping is directly related to the management adopted as a function of the production factors involved, such as the selection of crops and cultivars involved in the system, fertilizer quantities, and proportions of population densities (BATISTA et al., 2016; BEZERRA NETO et al., 2010; OLIVEIRA et al., 2015). New commercial vegetable cultivars are launched annually on the market by companies specialized in seed production, and among these are those recommended for the Northeast region. In this sense, it is of fundamental importance to know the behavior of these cultivars in terms of their greater or lesser competitive abilities, which provide good interspecific combining ability and, consequently, greater production and agroeconomic efficiency in intercropping systems (OLIVEIRA et al., 2004; PORTO et al., 2011).

Research has been carried out testing the behavior of vegetable crop cultivars in intercropping systems, demonstrating their adaptation to the cropping system. Lima et al. (2010), evaluating the behavior of arugula cultivars in two croppings with carrot cultivars, found an advantage in the association of the carrot "Brasília" with the arugula "Cultivada," presenting a land equivalent ratio (LER) of 1.45. Oliveira et al. (2005), evaluating the combination of commercial cultivars of coriander adapted to the conditions of the Brazilian northeast with lettuce cultivars, found greater biological efficiencies in the combinations of Tainá and Asteca, and Babá de Verão and Português, with LERs of 1.62 and 3.21, respectively. The intercropping systems of the carrot "Alvorada" + the lettuce "Lucy Brown" or the carrot "Brasília" + the lettuce "Lucy Brown" were those indicated to the producer, with LERs of 1.26 and 1.21, respectively (BEZERRA NETO et al., 2007).

Combinations of cultivars of leaf vegetable crops and tubers in polyculture can offer agroeconomic advantages. In view of this, we proposed with this work to evaluate combinations of cultivars of coriander and arugula in two croppings with carrot cultivars in a strip-intercropping system.

\section{MATERIAL AND METHODS}

The experiment was conducted under field conditions from November 2014 to March 2015 at 'Rafael Fernandes' farm of the Universidade Federal Rural do Semi-Árido (UFERSA) in the district of Alagoinha, $20 \mathrm{~km}$ from the municipality of Mossoró$\mathrm{RN}$, located at $5^{\circ} 03^{\prime}$ south latitude, $37^{\circ} 24^{\prime}$ west longitude, and $18 \mathrm{~m}$ altitude. According to Thornthwaite, the climate of the region is semi-arid and, according to Köppen, is BShw ', dry and very hot, with two seasons: a dry season, which usually goes from June to January, and a rainy season, from February to May (CARMO FILHO; ESPÍNOLA SOBRINHO; MAIA NETO, 1991).

The soil of the experimental area was classified as Alfissol eutrophic (SANTOS et al., 2006). Soil samples were collected at a depth of 0 $20 \mathrm{~cm}$ before the experiment installation, and they were dried in the ambient air and sieved in a 2-mm mesh and then analyzed in the Laboratory of Soil Chemistry and Fertility of the UFERSA, the results of which were as follows: $\mathrm{pH}$ (water) 7.1; $\mathrm{OM}=11.5 \mathrm{mg} \mathrm{dm} \mathrm{dm}^{-3} \mathrm{~N}=0.04 \mathrm{~g} \mathrm{~kg}^{-1}$ $\mathrm{P}=15.14 \mathrm{~g} \mathrm{~kg}^{-1} ; \mathrm{K}=50.5 \mathrm{mg} \mathrm{\textrm {dm } ^ { - 3 }}$; $\mathrm{Na}=4.1 \mathrm{mg} \mathrm{dm}{ }^{-3} ; \mathrm{Ca}=1.84 \mathrm{cmol}_{\mathrm{c}} \mathrm{dm}^{-3} ;$ $\mathrm{Mg}=1.4 \mathrm{cmol}_{\mathrm{c}} \mathrm{dm}^{-3}$; and CTC $=3.4 \mathrm{cmol}_{\mathrm{c}} \mathrm{dm}^{-3}$.

The experimental design used was in randomized complete blocks, with treatments arranged in a $2 \times 2 \times 2+2$ factorial scheme, with four replications. The treatments consisted of the combination of two cultivars of coriander (Verdão and Português) with two cultivars of carrot (Brasília and Esplanada) and two cultivars of arugula (Cultivada and Folha Larga) in a strip-intercropping system, plus two additional treatments, where the first was the cultivars in monocropping and the second one the cultivation systems (monocropping and intercropping).

The plots used in the intercropping of the experiment were established in alternating strips of the component cultures in the proportion of $25 \%$ of the area for coriander, $50 \%$ of the area for carrot, and $25 \%$ of the area for arugula, where each plot consisted of four rows of coriander alternated with four rows of carrot and four rows of arugula alternating with four rows of carrot, flanked by two rows of carrot surrounded on one side and two rows of coriander on the other side, thus constituting the lateral borders. The total area of the experimental plot was $4.80 \mathrm{~m}^{2}$, and the harvest area was $3.20 \mathrm{~m}^{2}$. The spacing used for coriander, carrot, and arugula was $0.20 \mathrm{~m} \times 0.05 \mathrm{~m}$, with two plants per hole for leafy vegetable crops and one plant per hole for carrot, containing 160 plants for all crops.

The plots in the monocrop had a total area of $1.44 \mathrm{~m}^{2}$, with a harvest area of $0.80 \mathrm{~m}^{2}$. For coriander and arugula, the spacing used was $0.20 \mathrm{~m} \times 0.05 \mathrm{~m}$, containing 80 plants, and for carrot, the spacing used $0.20 \mathrm{~m} \times 0.10 \mathrm{~m}$, containing 
40 plants. The recommended population for the monocrop for the region was $1,000.000$ plants per hectare for coriander and arugula (FREITAS et al., 2009; LIMA et al., 2007) and 500,000 plants per hectare for the cultivation of carrot (OLIVEIRA et al., 2004).

The preparation of the experimental area consisted of mechanical cleaning with a harrow with the aid of a tractor, followed by harrowing and lifting of the beds with a rotating hoe. Before the installation of the field experiment, a 45-day solarization of the planting beds was carried out using a 30-micron Brill Fles Vulcabrilho plastic with the objective of reducing the population of soil phytopathogens that would affect the productivity of the evaluated crops, especially Meloidogyne spp (SILVA et al., 2006)

The fertilization was performed with the green manure roostertree (Calotropis procera), with this green manure collected in the municipality of Quixeré-CE, Fazenda da Mizú, and the vegetative part of the plants was taken. After the collection, the plants were ground in a conventional forage machine, obtaining fragments between 2.0 and $3.0 \mathrm{~cm}$, and put to dry at full sun until reaching a moisture content of $10 \%$. Samples of this material were removed and sent for analysis of their chemical composition in the laboratory, obtaining the following results: $\mathrm{N}=15.3 \mathrm{~g} \mathrm{~kg}^{-1} ; \mathrm{P}=4.0 \mathrm{~g} \mathrm{~kg}^{-1}$; $\mathrm{K}=15.7 \mathrm{~g} \mathrm{~kg}{ }^{-1} ; \quad \mathrm{Ca}=9.3 \mathrm{~g} \mathrm{~kg}^{-1} ;$ and $\mathrm{Mg}=7.03 \mathrm{~g} \mathrm{~kg}^{-1}$, with a carbon/nitrogen ratio of 25: 1 .

The experimental plots in the intercropping system were fertilized using $45 \mathrm{t} \mathrm{ha}^{-1}$ of roostertree incorporated into the soil, an optimized amount in an experiment developed by Silva et al. (2013). The plots in the monocrop of carrot were fertilized with $42 \mathrm{t} \mathrm{ha}^{-1}$ (SILVA, 2014). Two incorporations of the green manure were carried out in the intercropped and sole crop plots of carrot, with $50 \%$ of the amounts incorporated in all plots intercropped at the planting beds in the $0-20 \mathrm{~cm}$ soil layer at 21 days before sowing of component crops intercropped, and the remaining $50 \%$ was incorporated at 45 days after carrot planting (CARVALHO, 2011).

The leafy vegetable crops were planted in two successive cropping (bicropping) during the carrot cycle, according to the methodology used by Lima et al. (2010). The monocrop plots of arugula and coriander were fertilized with 45 and $30 \mathrm{t} \mathrm{ha}^{-1}$, respectively, according to Silva (2012), with a $100 \%$ incorporation of this material performed at 20 days before each planting. After the incorporations, irrigations were carried out to promote the decomposition of the material until the planting and throughout the conduction of the experiment by a micro-sprinkler system, with a daily irrigation schedule divided into two applications (morning and afternoon), where a water slide of approximately $8 \mathrm{~mm} \mathrm{dia}^{-1}$ was supplied.
The vegetable crops were sown in simultaneous cultivation on November 24, 2014, in holes of approximately $2 \mathrm{~cm}$ depth, placing three to four seeds per hole. The roughing of arugula and coriander was performed at 10 and 12 days after sowing, respectively, leaving two plants per hole in the intercropped treatments and only one plant per hole in the single crop. The carrot thinning was done 16 days after sowing, leaving one plant per hole in the two cropping systems (intercropped and monocrop). Throughout the experiment, manual weedings were performed in order to keep the crops in the clean and for earthing up of carrot to prevent the incidence of green shoulder.

At 85 days after sowing the carrot, the second cropping of the leafy vegetable crops was performed. The thinning of these crops was carried out 10 days after sowing, leaving two seedlings per hole in the intercropping, and only one seedling per hole in the single crop plots. In order to reduce interspecific competition and shading of the leafy vegetables, the carrot was staked (lifting the stems).

The harvests of the arugula and coriander were carried out at 31 and 38 days after sowing, respectively, in both cultures. The carrot harvest occurred on March 4, 2015, at 105 days after sowing. The characteristics evaluated in coriander and arugula were yield of green mass (obtained by the fresh mass of the shoots of plants removed from the harvest area, expressed in $\mathrm{tha}^{-1}$ ) and dry mass of the shoots (obtained from a sample of 20 plants removed from the harvest area, where the dry mass of the plants was determined in a greenhouse with forced air circulation at $65^{\circ} \mathrm{C}$ until reaching constant mass and expressed in $\mathrm{tha}^{-1}$ ).

The following were analyzed in the carrot: dry mass of the shoots (determined in a sample of 15 plants, placing the vegetative part of the plants in paper bags and then in a forced circulation air oven at $65{ }^{\circ} \mathrm{C}$ until reaching constant mass, expressed in $\mathrm{t} \mathrm{ha} \mathrm{h}^{-1}$ ), dry mass of roots (obtained from the sample of the roots of the 15 plants sampled, placed in paper bags in a forced circulation air oven at $65^{\circ} \mathrm{C}$ until reaching constant mass and expressed in $\mathrm{t} \mathrm{ha}^{-1}$ ), total productivity of roots (determined from the root fresh mass of all plants of the harvest area, expressed in $\mathrm{tha}^{-1}$ ), commercial productivity of roots (obtained from the fresh mass of the roots of the plants of the harvest area, free of cracks, bifurcations, nematode, and mechanical damage, expressed as $\mathrm{t} \mathrm{ha}^{-1}$ ), and classified productivity of roots, which was determined from the length and greatest transverse diameter, in longs (length from 17 to $25 \mathrm{~cm}$ and diameter smaller than $5 \mathrm{~cm}$ ), means (12 to $17 \mathrm{~cm}$ in diameter and larger than $2.5 \mathrm{~cm}$ in diameter), shorts (5 to $12 \mathrm{~cm}$ in length and larger than $1 \mathrm{~cm}$ in diameter), and scrap (roots that do not fit into previous measurements), according to Lana and Vieira (2000), with this productivity expressed in $\mathrm{tha}^{-1}$ 
The agronomic efficiency of the polyculture systems was determined by the following indexes: land equivalent ratio, productive efficiency index and score of the canonical variable $\mathrm{Z}$.

The land equivalent ratio (LER) was obtained by the following expression:

LER $=\left(\mathrm{Y}_{\text {coac } 1 \mathrm{c}} / \mathrm{Y}_{\text {com1c }}\right)+\left(\mathrm{Y}_{\text {coac } 2 \mathrm{c}} / \mathrm{Y}_{\text {com2c }}\right)+$ $\left.\left(\mathrm{Y}_{\mathrm{ccoa}}\right) / \mathrm{Y}_{\mathrm{cm}}\right)+\left(\mathrm{Y}_{\mathrm{accolc}} / \mathrm{Y}_{\mathrm{am} 1 \mathrm{c}}\right)+\left(\mathrm{Y}_{\mathrm{acco} 2 \mathrm{c}} / \mathrm{Y}_{\mathrm{am} 2 \mathrm{c}}\right)$

Where:

$\mathrm{Y}_{\text {coaclc }}=$ Yield of coriander green mass $\left(\mathrm{Y}_{\mathrm{co}}\right)$ in polyculture with arugula $\left(_{a}\right)$ and carrot $\left(_{c}\right)$ in the first cultivation $\left({ }_{1 \mathrm{c}}\right)$;

$\mathrm{Y}_{\mathrm{com} 1 \mathrm{c}}=$ Yield of coriander green mass in monocrop $\left(\mathrm{Y}_{\text {com }}\right)$ in the first cultivation $(1 \mathrm{c})$;

$\mathrm{Y}_{\text {coac2c }}=$ Yield of coriander green mass $\left(\mathrm{Y}_{\mathrm{co}}\right)$ in polyculture with arugula $\left(_{a}\right)$ and carrot $\left(_{c}\right)$ in the second cultivation $(2 \mathrm{c})$;

$\mathrm{Y}_{\mathrm{com} 2 \mathrm{c}}=$ Yield of coriander green mass in monocrop $\left(\mathrm{Y}_{\mathrm{com}}\right)$ in the second cultivation $(2 \mathrm{c})$;

$\mathrm{Y}_{\mathrm{ccoa}}=$ Commercial productivity of carrot roots in polyculture $\left(\mathrm{Y}_{\mathrm{c}}\right)$ with coriander $\left.{ }_{\mathrm{co}}\right)$ and arugula $(\mathrm{a})$;

$\mathrm{Y}_{\mathrm{cm}}=$ Commercial productivity of carrot roots $\left(\mathrm{Y}_{\mathrm{c}}\right)$ in monocrop $(\mathrm{m})$;

$\mathrm{Y}_{\mathrm{accolc}}=$ Yield of arugula green mass $\left(\mathrm{Y}_{\mathrm{a}}\right)$ in polyculture with carrot $\left(_{c}\right)$ and coriander $\left.{ }_{(\mathrm{co}}\right)$ in the first cultivation $\left({ }_{1 \mathrm{c}}\right)$;

$\mathrm{Y}_{\mathrm{amlc}}=$ Yield of arugula green mass in monocrop $\left(\mathrm{Y}_{\mathrm{am}}\right)$ in the first cultivation $(1 \mathrm{c})$;

$\mathrm{Y}_{\mathrm{acco2c}}=$ Yield of arugula green mass $\left(\mathrm{Y}_{\mathrm{a}}\right)$ in polyculture with carrot $\left(_{c}\right)$ and coriander

$\left.{ }_{\mathrm{co}}\right)$ in the second cultivation $(2 \mathrm{c})$;

$\mathrm{Y}_{\mathrm{am} 2 \mathrm{c}}=$ Yield of arugula green mass in monocrop $\left(\mathrm{Y}_{\mathrm{am}}\right)$ in the second cultivation $(2 \mathrm{c})$;

The LERs of each plot were obtained by considering the mean of the single crop replicates over blocks in the denominator of the LER of each crop $\left(\mathrm{LER}_{\mathrm{co}} ; \mathrm{LER}_{\mathrm{c}} ; \mathrm{LER}_{\mathrm{a}}\right)$, as recommended by Bezerra Neto et al. (2012).

In the calculation of the productive efficiency of each treatment, the IEP model with constant returns to scale (CHARNES; COOPER; RHODES, 1978) was used, since there is no evidence of significant differences in scale. In addition to the other characteristics of each component crop, the efficiency of the intercropping system was also determined by the canonical variable score (Z), obtained through the multivariate analysis of variance of the coriander, carrot, and arugula productivities.

The economic efficiency indicator analyzed was gross income (GI), which was obtained by multiplying the crop productivity in each treatment by the value of the product paid to the producer, for coriander, carrot, and arugula. The amounts paid were $\mathrm{R} \$ 6.00 \mathrm{~kg}^{-1}, \mathrm{R} \$ 1.48 \mathrm{~kg}^{-1}$, and $\mathrm{R} \$ 1.40 \mathrm{~kg}^{-1}$, respectively. The net income was calculated by subtracting the costs of production from the GI, coming from inputs and services. These costs were calculated for each treatment based on the cost coefficients of inputs and services used in one hectare of each culture of coriander, carrot, and arugula at the experimental level. The prices of inputs and services in force in March 2015 in the city of Mossoró-RN were considered. The rate of return per invested real was obtained through the relation between the GI and the cost of production of each treatment. The profit margin, which was obtained from the relation between net income and GI, was expressed as a percentage (OLIVEIRA et al., 2004).

The monetary advantage (MA) was obtained by the ratio between the GI and the LER, expressed in Reals per hectare, calculated by the following equation: $\mathrm{MA}=\mathrm{GI} \times(\mathrm{LER}-1) / \mathrm{LER}$. The modified monetary advantage (MMA) was obtained by the following equation: MMA = NI x (LER - 1)/LER, expressed in Reals per hectare.

A univariate analysis of variance for factorial experiment designed in a randomized complete block with the additional treatments was performed to evaluate the characteristics studied in the coriander, carrot, and arugula through the software SISVAR, version 5.3 (FERREIRA, 2011). A multivariate analysis of variance was performed in the yields of the vegetable crops intercropped as a function of the treatment-factors. The Tukey test at 5\% probability was used to compare the means of the levels of these treatment-factors.

\section{RESULTS AND DISCUSSION}

\section{Coriander crop}

No significant interaction was observed among coriander, carrot, and arugula cultivars for shoot green mass yield and dry mass of these crops (Table 1). Significant differences between coriander cultivars and between cultivars of arugula in intercropping were observed only for green mass yield, providing the highest mean values in the "Português" $\left(1.39 \mathrm{t} \mathrm{ha}^{-1}\right)$ and "Cultivada" (1.48 $\left.\mathrm{t} \mathrm{ha}^{-1}\right)$ cultivars. This result indicates that the "Português" coriander and "Cultivada" arugula assumed the role of companion plants, since they were efficient in the use of production resources such as space, nutrients, water, and light (RESENDE et al., 2007).

Oliveira et al. (2005), analyzing the combination of coriander and lettuce cultivars in intercropping, observed a difference between coriander cultivars for coriander green mass yield, with "Português" standing out from the others. The "Português" coriander cultivar was better than 
"Verdão," probably because these conditions favored the development of this cultivar that developed faster than "Verdão," which translated into higher green mass yield in this intercropping. For this leafy vegetable crop, green mass yield is considered to be the most important characteristic for the producer, since it is the commercial part that attracts the consumer (MARQUES; LORENCETTI, 1999).

Table 1. Mean values of green mass yield (GMY) and shoot dry mass (SDM) of coriander as a function of intercropped coriander, carrot, and arugula cultivars; coriander cultivars in sole crops; and cropping systems.

\begin{tabular}{|c|c|c|}
\hline \multirow{3}{*}{ Cultivars } & \multicolumn{2}{|c|}{ Evaluated characteristics } \\
\hline & GMY $\left(\mathrm{t} \mathrm{ha}^{-1}\right)$ & $\operatorname{SDM}\left(\mathrm{t} \mathrm{ha}^{-1}\right)$ \\
\hline & \multicolumn{2}{|c|}{ Coriander cultivars in intercropping } \\
\hline Verdão & $1.09 \mathrm{~b}$ & $0.35 \mathrm{a}$ \\
\hline \multirow[t]{2}{*}{ Português } & $1.39 \mathrm{a}$ & $0.42 \mathrm{a}$ \\
\hline & \multicolumn{2}{|c|}{ Carrot cultivars in intercropping } \\
\hline Brasília & $1.21 \mathrm{a}$ & $0.41 \mathrm{a}$ \\
\hline \multirow[t]{2}{*}{ Esplanada } & $1.27 \mathrm{a}$ & $0.36 \mathrm{a}$ \\
\hline & \multicolumn{2}{|c|}{ Arugula cultivars in intercropping } \\
\hline Cultivada & $1.48 \mathrm{a}$ & $0.42 \mathrm{a}$ \\
\hline \multirow[t]{2}{*}{ Folha Larga } & $0.99 \mathrm{~b}$ & $0.35 \mathrm{a}$ \\
\hline & \multicolumn{2}{|c|}{ Coriander cultivars in sole crop } \\
\hline Verdão & $4.20 \mathrm{a}$ & $0.67 \mathrm{a}$ \\
\hline \multirow[t]{2}{*}{ Português } & $3.06 \mathrm{a}$ & $0.71 \mathrm{a}$ \\
\hline & \multicolumn{2}{|c|}{ Cropping systems } \\
\hline Intercropped & $1.24 \mathrm{~b}$ & $0.38 \mathrm{~b}$ \\
\hline Sole crop & $3.63 \mathrm{a}$ & $0.69 \mathrm{a}$ \\
\hline
\end{tabular}

*Means followed by different lowercase letters in the column differ statistically from each other by the Tukey test at the 5\% probability level.

The differentiation in the performances of coriander cultivars can be explained presumably by the high temperature and wide luminosity conditions, besides the differentiated adaptability of these genotypes to intercropping with carrot and arugula cultivars (OLIVEIRA et al., 2005). Significant differences between the cropping systems were recorded on the green mass yield and on the dry mass of the coriander shoots, with the single crop exceeding the crop intercropped in these characteristics (Table 1). This performance may be related to less intraspecific competition among coriander plants, which obtained better utilization of available resources, leading to higher productive performance.

\section{Carrot crop}

There was no significant interaction among the cultivars of the vegetable crops tested. Likewise, no significant differences were observed among the intercropped cultivars tested for any of the characteristics evaluated in the carrot (Table 2). On the other hand, analyzing carrot cultivars in single crop, we observed a significant difference between them only in the shoot dry mass, where "Brasília" presented the highest average $\left(2.82 \mathrm{t} \mathrm{ha}^{-1}\right)$.

For the cropping systems, we observed that the intercropping system exceeded the single crop in the shoot dry mass and root dry mass characteristics (Table 2). It is believed that due to the greater densification, the plants have to develop more and with this greater accumulation of dry mass of shoots and dry mass of roots. This result demonstrates the intercropping's cooperation in crop development due to the complementarity between them. This complementarity is probably due to the different forms in the plant architecture, establishing a better use of the available resources, such as water, light, and nutrients (MONTEZANO; PEIL, 2006). 
P. C. A. LINHARES et al.

Table 2. Mean values of shoot dry mass (SDM) and root dry mass (RDM) of carrot as a function of intercropped coriander, carrot, and arugula cultivars; carrot cultivars in sole crops; and cropping systems.

\begin{tabular}{|c|c|c|}
\hline \multirow{3}{*}{ Cultivars } & \multicolumn{2}{|c|}{ Evaluated characteristics } \\
\hline & $\operatorname{SDM}\left(\mathrm{t} \mathrm{ha}^{-1}\right)$ & $\operatorname{RDM}\left(\mathrm{t} \mathrm{ha}^{-1}\right)$ \\
\hline & \multicolumn{2}{|c|}{ Coriander cultivars in intercropping } \\
\hline Verdão & $3.51 \mathrm{a}$ & $2.21 \mathrm{a}$ \\
\hline \multirow[t]{2}{*}{ Português } & $3.34 \mathrm{a}$ & $2.46 \mathrm{a}$ \\
\hline & \multicolumn{2}{|c|}{ Carrot cultivars in intercropping } \\
\hline Brasília & $3.43 \mathrm{a}$ & $2.25 \mathrm{a}$ \\
\hline \multirow[t]{2}{*}{ Esplanada } & $3.42 \mathrm{a}$ & $2.42 \mathrm{a}$ \\
\hline & \multicolumn{2}{|c|}{ Arugula cultivars in intercropping } \\
\hline Cultivada & $3.39 \mathrm{a}$ & $2.39 \mathrm{a}$ \\
\hline \multirow[t]{2}{*}{ Folha Larga } & $3.46 \mathrm{a}$ & $2.27 \mathrm{a}$ \\
\hline & \multicolumn{2}{|c|}{ Carrot cultivars in sole crop } \\
\hline Brasília & $2.82 \mathrm{a}$ & $2.07 \mathrm{a}$ \\
\hline \multirow[t]{2}{*}{ Esplanada } & $2.08 \mathrm{~b}$ & $1.76 \mathrm{a}$ \\
\hline & \multicolumn{2}{|c|}{ Cropping systems } \\
\hline Intercropped & $3.42 \mathrm{a}$ & $2.33 \mathrm{a}$ \\
\hline Sole crop & $2.45 \mathrm{~b}$ & $1.91 \mathrm{~b}$ \\
\hline
\end{tabular}

*Means followed by different lowercase letters in the column differ statistically from each other by the Tukey test at the $5 \%$ probability level.

Trenbath (1976) states that where soil nutrient conditions are suitable for cultivation, the competition for light is more intense, and the use of higher densities is recommended. These factors can lead to strong competition effects, with competition for light being higher, and consequently the plants need more development so that they can compete more for this resource (BEZERRA NETO et al., 2005). Another interesting factor that probably has occurred for this result of the intercropping system is the below-ground competition among the different associated plants. For under-ground competition for plants of different species, there may be a competitive difference if the competitive abilities of the root systems of these species are very different (FRANSEN; KROON; BERENDSE, 2001).

Significant differences were observed between coriander cultivars in the commercial and classified productivity of carrot roots, longs and shorts, presenting the highest means in the commercial and classified productivity of short roots (21.54 and $6.22 \mathrm{tha}^{-1}$ ), respectively. These values of commercial productivity and shorts are associated with the "Verdão" coriander cultivar, whereas the value of longs is associated with the "Português" coriander cultivar (Table 3 ).

A significant difference between carrot cultivars in single crop was recorded in long root productivity, where "Esplanada" presented the highest average $\left(7.18 \mathrm{t} \quad \mathrm{ha}^{-1}\right)$, surpassing "Brasília" (Table 3). This result for "Esplanada" is due to the peculiar characteristic of this cultivar, which tends to produce longer and thinner roots, suitable for the minimum processing aiming at the production of cenourete (VIEIRA et al., 2005). Teófilo et al. (2009) state that the plant initially intended photoassimilates produced to the formation of structures of the aerial part aiming to increase the leaf area until a certain period, since the tendency is that most of the photoassimilates produced are destined to the structures of reserves (drains), which in the case of carrot is the root.

There were also significant differences between cropping systems in the total and commercial productivity, and yield of medium and short roots with monocrop, standing out from intercropping (Table 3). According to Zanine and Santos (2004), a considerable reduction in species growth - both in intraspecific combinations, when the plants compete with each other, and interspecific when competing with other plants - results from the spatial competition between groups of plants that occupy the same place in a given period of time. In this case, these characteristics suffered less influence from intraspecific competition, resulting in higher performance when in single crop. 
Table 3. Mean values of total (TP) and commercial productivity (CP) of roots, classified productivity of root longs (LR), media (MR), shorts (SR), and scraps ( $\mathrm{ScR}$ ) of carrot as a function of intercropped coriander, carrot, and arugula cultivars; carrot cultivars in sole crops; and cropping systems.

\begin{tabular}{|c|c|c|c|c|c|c|}
\hline \multirow{3}{*}{ Cultivars } & \multicolumn{6}{|c|}{ Evaluated characteristics } \\
\hline & $\mathrm{TP}\left(\mathrm{tha}^{-1}\right)$ & $\mathrm{CP}\left(\mathrm{t} \mathrm{ha}^{-1}\right)$ & $\operatorname{LR}\left(\mathrm{t} \mathrm{ha}^{-1}\right)$ & $\operatorname{MR}\left(\mathrm{t} \mathrm{ha}^{-1}\right)$ & $\mathrm{SR}\left(\mathrm{t} \mathrm{ha}{ }^{-1}\right)$ & $\operatorname{ScR}\left(\mathrm{t} \mathrm{ha}^{-1}\right)$ \\
\hline & \multicolumn{6}{|c|}{ Coriander cultivars in intercropping } \\
\hline Verdão & $23.86 \mathrm{a}$ & $21.54 \mathrm{a}$ & $2.46 \mathrm{~b}$ & $12.82 \mathrm{a}$ & $6.22 \mathrm{a}$ & $2.32 \mathrm{a}$ \\
\hline \multirow[t]{2}{*}{ Português } & $22.34 \mathrm{a}$ & $19.08 \mathrm{~b}$ & $5.80 \mathrm{a}$ & $11.69 \mathrm{a}$ & $1.59 \mathrm{~b}$ & $3.26 \mathrm{a}$ \\
\hline & \multicolumn{6}{|c|}{ Carrot cultivars in intercropping } \\
\hline Brasília & $22.23 \mathrm{a}$ & $19.26 \mathrm{a}$ & $3.77 \mathrm{a}$ & $11.65 \mathrm{a}$ & $3.84 \mathrm{a}$ & $2.97 \mathrm{a}$ \\
\hline \multirow[t]{2}{*}{ Esplanada } & $23.97 \mathrm{a}$ & $21.35 \mathrm{a}$ & $4.51 \mathrm{a}$ & $12.87 \mathrm{a}$ & $3.97 \mathrm{a}$ & $2.62 \mathrm{a}$ \\
\hline & \multicolumn{6}{|c|}{ Arugula cultivars in intercropping } \\
\hline Cultivada & $23.56 \mathrm{a}$ & $20.45 \mathrm{a}$ & $4.56 \mathrm{a}$ & $12.25 \mathrm{a}$ & $3.63 \mathrm{a}$ & $3.11 \mathrm{a}$ \\
\hline \multirow[t]{2}{*}{ Folha Larga } & $22.64 \mathrm{a}$ & $20.17 \mathrm{a}$ & $3.72 \mathrm{a}$ & $12.26 \mathrm{a}$ & $4.18 \mathrm{a}$ & $2.47 \mathrm{a}$ \\
\hline & \multicolumn{6}{|c|}{ Carrot cultivars in sole crop } \\
\hline Brasília & $44.42 \mathrm{a}$ & $42.47 \mathrm{a}$ & $1.66 \mathrm{~b}$ & $23.80 \mathrm{a}$ & $17.02 \mathrm{a}$ & $1.95 \mathrm{a}$ \\
\hline \multirow[t]{2}{*}{ Esplanada } & $37.89 \mathrm{a}$ & $34.51 \mathrm{a}$ & $7.18 \mathrm{a}$ & $21.08 \mathrm{a}$ & $6.25 \mathrm{a}$ & $3.37 \mathrm{a}$ \\
\hline & \multicolumn{6}{|c|}{ Cropping systems } \\
\hline Intercropped & $23.10 \mathrm{~b}$ & $20.31 \mathrm{~b}$ & $4.14 \mathrm{a}$ & $12.26 \mathrm{~b}$ & $3.90 \mathrm{~b}$ & $2.79 \mathrm{a}$ \\
\hline Sole crop & $41.16 \mathrm{a}$ & $38.49 \mathrm{a}$ & $4.42 \mathrm{a}$ & $22.44 \mathrm{a}$ & $11.64 \mathrm{a}$ & $2.67 \mathrm{a}$ \\
\hline
\end{tabular}

*Means followed by different lowercase letters in the column differ statistically from each other by the Tukey test at the $5 \%$ probability level.

\section{Arugula crop}

For green mass yield and dry mass of shoots, no significant interaction was observed among the cultivars of coriander, carrot, and arugula (Table 4). A significant difference was registered only between the coriander cultivars in the intercropping in the arugula green mass yield, with the "Português" coriander cultivar presenting the highest yield of $3.05 \mathrm{t} \mathrm{ha}^{-1}$, standing out from "Verdão." This behavior is probably due to the different plant species that were intercropped, with complementarity between them to make better use of available resources, conferring on them the condition of companion plants (GRANGEIRO et al., 2011).

Table 4. Mean values of green mass yield (GMY) and shoot dry mass (SDM) of arugula as a function of intercropped coriander, carrot, and arugula cultivars; carrot cultivars in sole crops; and cropping systems.

\begin{tabular}{|c|c|c|}
\hline \multirow{3}{*}{ Cultivars } & \multicolumn{2}{|c|}{ Evaluated characteristics } \\
\hline & GMY $\left(\mathrm{t} \mathrm{ha}^{-1}\right)$ & $\operatorname{SDM}\left(\mathrm{t} \mathrm{ha}^{-1}\right)$ \\
\hline & \multicolumn{2}{|c|}{ Coriander cultivars in intercropping } \\
\hline Verdão & $2.54 \mathrm{~b}$ & $0.80 \mathrm{a}$ \\
\hline \multirow[t]{2}{*}{ Português } & $3.05 \mathrm{a}$ & $0.88 \mathrm{a}$ \\
\hline & \multicolumn{2}{|c|}{ Carrot cultivars in intercropping } \\
\hline Brasília & $2.86 \mathrm{a}$ & $0.85 \mathrm{a}$ \\
\hline \multirow[t]{2}{*}{ Esplanada } & $2.72 \mathrm{a}$ & $0.83 \mathrm{a}$ \\
\hline & \multicolumn{2}{|c|}{ Arugula cultivars in intercropping } \\
\hline Cultivada & $2.88 \mathrm{a}$ & $0.88 \mathrm{a}$ \\
\hline \multirow[t]{2}{*}{ Folha Larga } & $2.70 \mathrm{a}$ & $0.80 \mathrm{a}$ \\
\hline & \multicolumn{2}{|c|}{ Arugula cultivars in sole crop } \\
\hline Cultivada & $8.81 \mathrm{a}$ & $1.23 \mathrm{a}$ \\
\hline \multirow[t]{2}{*}{ Folha Larga } & $8.21 \mathrm{a}$ & $1.17 \mathrm{a}$ \\
\hline & \multicolumn{2}{|c|}{ Cropping systems } \\
\hline Intercropped & $2.79 \mathrm{~b}$ & $0.84 \mathrm{~b}$ \\
\hline Sole crop & $8.51 \mathrm{a}$ & $1.20 \mathrm{a}$ \\
\hline
\end{tabular}

*Means followed by different lowercase letters in the column differ statistically from each other by the Tukey test at the $5 \%$ probability level.

Rev. Caatinga, Mossoró, v. 30, n. 3, p. 622 - 632, jul. - set., 2017 
Between the cropping systems, there was a significant difference in the green mass yield and shoot dry mass, with single crop standing out from the intercropping (Table 4). The arugula obtained better productive performance in single culture, possibly because there was no interspecific competition, only a small intraspecific competition (ZANINE; SANTOS, 2004); however, it represented an additional source of income for the system.

\section{Agronomic/biological indices}

Significant interaction among coriander, carrot, and arugula cultivars was found only for the canonical variable score (Table 5). A significant difference between coriander cultivars was recorded only when they were associated with the "Esplanada" carrot cultivar, with the "Português" coriander cultivar presenting the highest score (2.05). On the other hand, a significant difference between carrot cultivars was observed when they were associated with the "Português" coriander, with the cultivar "Esplanada" standing out from "Brasília." Between the cultivars of arugula, a significant difference was also observed, with "Cultivada" differing from "Folha Larga." The multivariate analysis of variance of crop yield proved very informative and advantageous due to the higher discriminant capacity, besides the description of the relative superiority of the treatments (BEZERRA NETO et al., 2007).

Table 5. Mean values of the canonical variable score $(\mathrm{Z})$ as a function of intercropped coriander, carrot, and arugula cultivars.

\begin{tabular}{ccc}
\hline \multirow{2}{*}{ Coriander cultivars in intercropping } & \multicolumn{2}{c}{ Score of the canonical variable $(\mathrm{Z})$} \\
\cline { 2 - 3 } & \multicolumn{2}{c}{ Carrot cultivars in intercropping } \\
\cline { 2 - 3 } & \multicolumn{2}{c}{ Brasília } \\
\hline Verdão & $1.58 \mathrm{aA}$ & \multicolumn{1}{c}{ Esplanada } \\
\hline Português & $1.73 \mathrm{aB}$ & $2.05 \mathrm{aA}$ \\
\hline Arugula cultivars in intercropping & & $1.92 \mathrm{a}$ \\
\hline Cultivada & $1.51 \mathrm{~b}$ \\
Folha Larga & & \\
\hline
\end{tabular}

*Means followed by different lowercase letters in the column differ statistically from each other by the Tukey test at the 5\% probability level.

This result reinforces the better productive performance of the "Português" coriander cultivars, carrot "Esplanada," as well as the "Cultivada" arugula. The best combinations between species in intercropping are those in which there is high complementation between them due to their different forms in the architecture, making better use of available resources (CECÍLIO FILHO et al., 2015).
A significant difference was recorded among coriander cultivars in the LER, with the "Português" cultivar presenting the best LER of 2.21 (Table 6). In this way, it can be seen that there was adaptability of "Português" to the intercropped system, expressing itself in better use of environmental resources and land.

Table 6. Mean values of the land equivalent ratio (LER) and productive efficiency index (PEI) as a function of intercropped coriander, carrot, and arugula cultivars.

\begin{tabular}{ccc}
\hline \multirow{2}{*}{ Cultivars } & \multicolumn{3}{c}{ Evaluated characteristics } \\
\cline { 2 - 4 } & LER & PEI \\
\hline & \multicolumn{2}{c}{ Coriander cultivars in intercropping } \\
\hline Verdão & $1.74 \mathrm{~b}$ & $0.83 \mathrm{a}$ \\
Português & $2.21 \mathrm{a}$ & $0.87 \mathrm{a}$ \\
\hline & \multicolumn{3}{c}{ Carrot cultivars in intercropping } \\
\hline Brasília & $1.94 \mathrm{a}$ & $0.84 \mathrm{a}$ \\
Esplanada & $2.02 \mathrm{a}$ & $0.86 \mathrm{a}$ \\
\hline & \multicolumn{3}{c}{ Arugula cultivars in intercropping } \\
\hline Cultivada & $2.13 \mathrm{a}$ & $0.89 \mathrm{a}$ \\
Folha Larga & $1.83 \mathrm{~b}$ & $0.81 \mathrm{~b}$ \\
\hline
\end{tabular}

*Means followed by different lowercase letters in the column differ statistically from each other by the Tukey test at the $5 \%$ probability level. 
For cultivars of arugula, significant differences in LER and PEI were observed, with "Cultivada" differing from "Folha Larga," presenting the highest results (2.13 for LER and 0.89 for PEI). This indicates that there was adaptability of the cultivar "Cultivada" in this association, demonstrating better agronomic/biological efficiency. The carrot cultivars presented no significant difference for any of the indices analyzed.

Regardless of the cultivar combinations used in the intercropping, all LERs were higher than one (unit). This result confirms that the intercropped system favored the growth and production of the vegetable crops, confirming that there was a greater use of environmental resources, meaning that the intercropping was viable (REZENDE et al., 2010). LERs ranged from 1.83 to 2.24 , meaning that at least $83 \%$ to $124 \%$ more area would be required for crops in monocrop to produce the equivalent of the intercropping production on one hectare.

\section{Economic indicators}

There was no significant interaction among the cultivars of coriander, carrot, and arugula for any of the economic indicators studied (Table 7). However, a significant difference was registered between the cultivars of coriander only on MA and MMA, with the "Português" coriander cultivar standing out from "Verdão" in these economic indicators. This result is associated to the fact that the "Português" coriander expressed better efficient use of the land, and thus this agronomic superiority translated into economic gain (OLIVEIRA et al., 2005).

Table 7. Mean values of gross income (GI), net income (NI), rate of return (RR), profit margin (PM), monetary advantage (MA), and modified monetary advantage (MMA) as a function of intercropped coriander, carrot, and arugula cultivars.

\begin{tabular}{|c|c|c|c|c|c|c|}
\hline \multirow{3}{*}{ Cultivars } & \multicolumn{6}{|c|}{ Evaluated characteristics } \\
\hline & $\begin{array}{c}\text { GI } \\
\left(\mathrm{R} \$ \mathrm{ha}^{-1}\right)\end{array}$ & $\begin{array}{c}\mathrm{NI} \\
\left(\mathrm{R} \$ \mathrm{ha}^{-1}\right)\end{array}$ & $\mathrm{RR}$ & PM (\%) & $\begin{array}{c}\text { MA } \\
\left(\mathrm{R} \$ \mathrm{ha}^{-1}\right)\end{array}$ & $\begin{array}{c}\text { MMA } \\
\left(\mathrm{R} \$ \mathrm{ha}^{-1}\right)\end{array}$ \\
\hline & \multicolumn{6}{|c|}{ Coriander cultivars in intercropping } \\
\hline Verdão & $45,380.00 \mathrm{a}$ & $17,113.00 \mathrm{a}$ & $1.60 \mathrm{a}$ & $36.97 \mathrm{a}$ & $19,314.00 \mathrm{~b}$ & $7,404.90 \mathrm{~b}$ \\
\hline \multirow[t]{2}{*}{ Português } & $45,660.00 \mathrm{a}$ & $17,315.00 \mathrm{a}$ & $1.61 \mathrm{a}$ & $37.23 \mathrm{a}$ & $24,878.00 \mathrm{a}$ & $9,617.30 \mathrm{a}$ \\
\hline & \multicolumn{6}{|c|}{ Carrot cultivars in intercropping } \\
\hline Brasília & $44,149.00 \mathrm{~b}$ & $15,872.00 \mathrm{a}$ & $1.56 \mathrm{a}$ & $35.35 \mathrm{a}$ & $21,021.00 \mathrm{a}$ & $7,712.40 \mathrm{a}$ \\
\hline \multirow[t]{2}{*}{ Esplanada } & $46,891.00 \mathrm{a}$ & $18,556.00 \mathrm{a}$ & $1.65 \mathrm{a}$ & $38.86 \mathrm{a}$ & $23,170.00 \mathrm{a}$ & $9,309.90 \mathrm{a}$ \\
\hline & \multicolumn{6}{|c|}{ Arugula cultivars in intercropping } \\
\hline Cultivada & $47,772.00 \mathrm{a}$ & $19,472.00 \mathrm{a}$ & $1.69 \mathrm{a}$ & $40.25 \mathrm{a}$ & $24,858.00 \mathrm{a}$ & $10,284.00 \mathrm{a}$ \\
\hline Folha Larga & $43,268.00 \mathrm{~b}$ & $14,956.00 \mathrm{~b}$ & $1.53 \mathrm{~b}$ & $33.96 \mathrm{~b}$ & $19,333.00 \mathrm{~b}$ & $6,738.30 \mathrm{~b}$ \\
\hline
\end{tabular}

*Means followed by different lowercase letters in the column differ statistically from each other by the Tukey test at the $5 \%$ probability level.

We also observed that the carrot cultivars differed only in the GI, with the "Esplanada" carrot cultivar showing the highest result. This result is related to the fact that this cultivar presented, on average, higher total production and, consequently, higher GI. For the cultivars of arugula, significant differences were also registered in the economic indicators, especially the "Cultivada" arugula, which presented the highest results (Table 7). This is due to the fact that this cultivar expressed better agronomic/ biological efficiency.

The results found in the present research are below those found by Oliveira et al. (2004), who evaluated the agroeconomic performance of lettuce cultivars in a monocrop and intercropping system with two carrot cultivars and found that the carrots "Alvorada" and "Lucy Brown" and the carrots "Brasília" and "Maravilha das Quatro Estações" had the best economic indicators in net revenues of $\mathrm{R} \$ 21,272.67 \mathrm{ha}^{-1}$ and $\mathrm{R} \$ 23,307.15 \mathrm{ha}^{-1}$, rates of return of 2.05 and 2.33 , and profit margins of $53.92 \%$ and $59.83 \%$, respectively.

\section{CONCLUSION}

The best association was the one that involved the "Português" coriander cultivar, the "Esplanada" carrot cultivar, and the "Cultivada" arugula cultivar.

\section{ACKNOWLEDGEMENTS}

Special thanks are due to the Conselho Nacional de Desenvolvimento Científico e Tecnológico (CNPq) for the financial support of this work and to the research group at the Crop Science Department of the Universidade Federal Rural do Semi-Árido (UFERSA), which develops technologies for growing vegetable crops on family farms.

\section{REFERÊNCIAS}

BATISTA, T. M. V. et al. Agronomic efficiency of 
the intercropping of arugula with carrot under different population combinations. Revista Caatinga, Mossoró, v. 29, n. 1, p. 76-84, 2016.

BEZERRA NETO, F. et al. Assessment of agroeconomic indices in polycultures of lettuce, rocket and carrot through uni and multivariate approaches in semi-arid Brazil. Ecological Indicators, New York, v. 1, n. 14, p. 11-17, 2012.

BEZERRA NETO, F. et al. Associação de densidades populacionais de cenoura e alface no desempenho agronômico da cenoura em cultivo consorciado em faixa. Horticultura Brasileira, Brasília, v. 23, n. 2, p. 233-237, 2005.

BEZERRA NETO, F. et al. Desempenho de sistemas consorciados de cenoura e alface avaliados através de métodos uni e multivariados. Horticultura Brasileira, Brasília, v. 25, n. 4, p. 514-520, 2007.

BEZERRA NETO, F. et al. Evaluation of yield advantage indexes in carrot-lettuce intercropping systems. Interciencia, Caracas, v. 35, n. 1, p. 59-64, 2010.

CARMO FILHO, F.; ESPÍNOLA SOBRINHO, J.; MAIA NETO, J. M. Dados climatológicos de Mossoró: um município semi-árido nordestino. Mossoró: ESAM, 1991. 121 p. (Coleção Mossoroense, C. 30).

CARVAlHO, F. W. A. D. Tamanho de parcela e viabilidade agroeconômica do consórcio cenoura e rúcula. 2011. $79 \mathrm{f}$. Tese (Doutorado em Fitotecnia: Área de concentração em Agricultura Tropical) - Universidade Federal Rural do Semi-Árido, Mossoró, 2011.

CECÍLIO FILHO, A. B. et al. Indices of bio-agroeconomic efficiency in intercropping systems of cucumber and lettuce in greenhouse. Australian Journal of Crop Science, Lismore, v. 9, n. 12, p. 1154-1164, 2015.

CHARNES, A.; COOPER, W. W.; RHODES, E. Measuring the efficiency of decision-making units. European Journal of Operational Research, Amsterdam, v. 2, n. 6, p. 429-444, 1978.

FERREIRA, D. F. Sisvar: a computer statistical analysis system. Ciência e Agrotecnologia, Lavras, v. 35 , n. 6 , p. 1039-1042, 2011.

FRANSEN, B.; KROON, H.; BERENDSE, F. Soil nutrient heterogeneity alters competition between two perennial grass species. Ecology, Washington, v. 82, n. 9, p. 2534-2546, 2001.

FREITAS, K. K. C. et al. Desempenho agronômico de rúcula sob diferentes espaçamentos e épocas de plantio. Revista Ciência Agronômica, Fortaleza, v. 40, n. 3, p. 449-454, 2009.

GRANGEIRO, L. C. et al. Avaliação agroeconômica das culturas da beterraba e coentro em função da época de estabelecimento do consórcio. Revista Ciência Agronômica, Fortaleza, v. 42, n. 1, p. 242-248, 2011.

LANA, M. M.; VIEIRA, J. V. Fisiologia e manuseio pós-colheita de cenoura. Brasília: Embrapa Hortaliças, 2000. 15 p. (Circular Técnica, 21).

LIMA, J. S. S. et al. Desempenho agroeconômico de coentro em função de espaçamentos e em dois cultivos. Revista Ciência Agronômica, Fortaleza, v. 38 , n. 4, p. 407-413, 2007

LIMA, J. S. S. et al. Productive performance of carrot and rocket cultivars in strip-intercropping system and sole crops. Agrociência, Montecillo, v. 44, n. 5, p. 561-574, 2010.

LIMA, J. S. S. et al. Produtividade da cenoura, coentro e rúcula em função de densidades populacionais. Revista Verde de Agroecologia e Desenvolvimento Sustentável, Mossoró, v. 8, n. 1, p. 110-116, 2013.

MARQUES, F. C.; LORENCETTI, B. L. Avaliação de três cultivares de coentro (Coriandrum sativum L.) semeadas em duas épocas. Pesquisa Agropecuária Gaúcha, Porto Alegre, v. 5, n. 2, p. 265-270, 1999.

MONTEZANO, E. M.; PEIL, R. M. N. Sistemas de consórcio na produção de hortaliças. Revista Brasileira de Agrociência, Pelotas, v. 12, n. 2, p. 129-132, 2006.

OLIVEIRA, E. Q. et al. Desempenho agroeconômico do bicultivo de alface em sistema solteiro e consorciado com cenoura. Horticultura Brasileira, Brasília, v. 22, n. 4, p. 712-717, 2004.

OLIVEIRA, E. Q. et al. Produção e valor agroeconômico no consórcio entre cultivares de coentro e de alface. Horticultura Brasileira, Brasília, v. 23, n. 2, p. 285-289, 2005.

OLIVEIRA, L. A. A. et al. Viabilidade agronômica de policultivos de rúcula/cenoura/alface sob quantidades de flor-de-seda e densidades populacionais. Revista Caatinga, Mossoró, v. 28, n. 4, p. 116-126, 2015.

PORTO, V. C. N. et al. Combination of lettuce and rocket cultivars in two cultures intercropped with carrots. Horticultura Brasileira, Brasília, v. 29, n 
3, p. 404-411, 2011.

RESENDE, F. V. et al. Cultivo de alface em sistema orgânico de produção. Brasília: Embrapa Hortaliças, 2007. 16 p. (Embrapa Hortaliças. Circular Técnica, 56).

REZENDE, B. L. A. et al. Análise econômica de cultivos consorciados de alface americana $\mathrm{x}$ rabanete: um estudo de caso. Horticultura Brasileira, Brasília, v. 23, n. 3, p. 853-858, 2005.

REZENDE, B. L. A. et al. Consórcios de alface crespa e pepino em função da população do pepino e época de cultivo. Interciencia, Caracas, v. 35, n. 5, p. 374-379, 2010.

SANTOS, H. G. et al. Sistema brasileiro de classificação de solos. 2. ed. Rio de Janeiro, RJ: EMBRAPA, 2006. 306 p.

SILVA, M. G. et al. Efeito da solarização, adubação química e orgânica no controle de nematóides em alface sob cultivo protegido. Horticultura Brasileira, Brasília, v. 24, n. 4, p. 489-494, 2006.

SILVA, M. L. et al. Produção de cenoura fertilizada com flor-de-seda (Calotropis procera (Ait.) R. Br.). Revista Ciência Agronômica, Fortaleza, v. 44, n. 4, p. 732-740, 2013.

SILVA, M. L. Viabilidade agronômica de hortaliças fertilizadas com flor-de-seda (Calotropis procera (Ait.) R.Br.). 2012. 83 f. Tese (Doutorado em Fitotecnia: Área de concentração em Agricultura Tropical) - Universidade Federal Rural do Semi-Árido, Mossoró, 2012.

SILVA, R. C. P. Adubação verde com espécie espontânea no consórcio de cenoura e alface em bicultivo sob diferentes quantidades de biomassa e arranjos espaciais. 2014. 71 f. Dissertação (Mestrado em Fitotecnia: Área de concentração em Agricultura Tropical) - Universidade Federal Rural do Semi-Árido, Mossoró, 2014.

VIEIRA, J. V. et al. Esplanada: cultivar de cenoura de verão para fins de processamento. Horticultura Brasileira, Brasília, v. 23, n. 3, p. 851-852, 2005.

TEÓFILO, T. M. S. et al. Crescimento de cultivares de cenoura nas condições de Mossoró-RN. Revista Caatinga, Mossoró, v. 22, n. 1, p. 168-174, 2009.

TRENBATH, B. R. Plant interaction in mixed crop communities. In: PAPENDICK, R. I.; SANCHEZ, A.; TRIPLETT, G. B. (Eds.). Multiple Cropping. Madison: American Society of Agronomy, 1976. p. 129-169. (ASA. Special Publication, 27).
ZANINE, A. M.; SANTOS, E. M. Competição entre espécies de plantas - uma revisão. Revista da Faculdade de Zootecnia, Veterinária e Agronomia, Uruguaiana, v. 11, n. 1, p. 10-30. 2004. 